\title{
TENSIOMETRIC ANALYSIS OF MESHES USED IN ABDOMINAL VENTRAL WALL DEFECTS IN RATS
}

\author{
Estudo tensiométrico de telas utilizadas na correção de defeito na parede abdominal ventral de ratos \\ Carlos Alberto Lima UTRABO 1,2, Nicolau Gregori CZECZKO', Cesar Roberto BUSATO², \\ Mário Rodrigues MONTEMÓR-NETTO ${ }^{2}$, Leandro LIPINSKI ${ }^{2}$, Osvaldo MALAFAIA ${ }^{1}$
}

From the ${ }^{1}$ Programa de Pós-Graduação em Princípios da Cirurgia, Faculdade Evangélica do Paraná, Curitiba, PR and 'Faculdade de Medicina, Universidade Estadual de Ponta Grossa (Postgraduate Program in Principles of Surgery, Evangelic Faculty of Paraná and Medical School, State University of Ponta Grossa), Ponta Grossa, PR, Brazil

HEADINGS - Surgical mesh. Polypropylene. Polyglecaprone. Tensiometry. Abdominal hérnia. Rats.
ABSTRACT - Background: Among the various strategies to avoid exaggerated foreign body reaction in the treatment of hernias is the limitation of the amount of polypropylene or the use of absorbable material. Aim: To evaluate the healing of defects in the abdominal wall of rats, comparing microporous polypropylene, macroporous polypropylene and polypropylene/polyglecaprone at the $30^{\circ}, 60^{\circ}$ and $120^{\circ}$ postoperative day. Methods: Wistar rats were submitted to defect production in the ventral abdominal wall, with integrity of the parietal peritoneum. Prolene ${ }^{\oplus}$, Ultrapro ${ }^{\oplus}$ and Bard Soft $^{\star}$ meshes were used in the correction of the defect. Nine subgroups of 10 animals were submitted to euthanasia at $30^{\text {th }}, 60^{\text {th }}$ and $120^{\text {th }}$ postoperative day. Fragments of the abdominal wall of the animals were submitted to tensiometric analysis. Results. The tensiometry at the $30^{\text {th }}$ postoperative day showed greater resistance of the tissues with Bard Soft ${ }^{\circledR}$ (macroporous mesh) in relation to the tissues with Prolene ${ }^{\oplus}$ (microporous mesh). On the $60^{\text {th }}$ postoperative day Bard Soft ${ }^{\oplus}$ maintained the superior resistance to the tissues comparing to Prolene Mesh ${ }^{\circledR}$. On the $120^{\text {th }}$ postoperative day the tissues repaired with Ultrapro ${ }^{\oplus}$ (macroporous mesh) proved to be more resistant than the ones by Prolene ${ }^{\circledast}$ (microporous mesh) and Bard Soft ${ }^{\oplus}$ (macroporous mesh). Conclusion: The tissues repaired with macroporous meshes showed greater resistance than with microporous meshes at all stages, and at 120 days postoperative Ultrapro ${ }^{\circledR}$ performed better than the others.

\section{Correspondence:}

Carlos Alberto Lima Utrabo

E-mail: carlosutrabo@uol.com.br.

Financial source: none

Conflict of interest: none.

Received for publication:12/04/2017 Accepted for publication: 18/07/2017

DESCRITORES - Tela cirúrgica. Polipropileno. Poliglecaprone. Tensiometria. Hérnia. Ratos.
RESUMO - Racional: Dentre as várias estratégias para evitar exagerada reação de corpo estranho no tratamento das hérnias está a limitação da quantidade de polipropileno na tela ou utilização de material absorvível. Objetivo: Avaliar a cicatrização de defeito em parede abdominal de ratos, comparando-se as telas de polipropileno microporosa, polipropileno macroporosa e polipropileno/poliglecaprone. Métodos: Em 90 ratos Wistar foi produzido defeito na parede abdominal ventral, com integridade do peritônio parietal. Na correção foram utilizadas as telas Prolene ${ }^{\circledR}$, Ultrapro ${ }^{\circledR}$ e Bard Soft ${ }^{\circledR}$. Nove subgrupos de 10 animais foram submetidos à eutanásia no $30^{\circ}, 60^{\circ}$ e $120^{\circ}$ dia do pós-operatório. Fragmentos da parede abdominal dos animais foram submetidos à análise tensiométrica. Resultados: A tensiometria aos 30dias mostrou maior resistência do tecido com tela Bard $\mathrm{Soft}^{\oplus}$ em relação à de Prolene ${ }^{\oplus}$; no $60^{\circ}$ dia a Bard Soft $^{\oplus}$ manteve a resistência superior ao Prolene ${ }^{\oplus}$; no $120^{\circ}$ dia a reparação com tela macroporosa Ultrapro ${ }^{\circledast}$ mostrou-se mais resistentes que a de Prolene $^{\oplus}$ e Bard Soft ${ }^{\oplus}$. Conclusão: Os tecidos reparados com telas macroporosas demonstraram maior resistência do que as microporosas em todas as fases, sendo que aos 120 dias de pós-operatório a Ultrapro ${ }^{\circledR}$ teve melhor desempenho que as demais.

\section{INTRODUCTION}

$\mathrm{T}$ he standard procedure for the surgical correction of the incisional hernia is performed with the use of meshes ${ }^{3,7,12}$. The most widely used material is polypropylene which causes rapid acute inflammatory response followed by chronic foreign body reaction that persists for months and years after the surgical procedure. Among the various strategies used to avoid exaggerated foreign body reaction is the limitation of the amount of polypropylene or the use of absorbable material that provides initial resistance and is quickly reabsorbed by reducing local inflammation ${ }^{14}$.

Studies focusing on the behavior of macroporous prosthetic material, including polypropylene, have been focused on the geometry and quantity of the implanted material. Attempts to reduce the amount of foreign body focused on the design of the macropores and the absorbable and nonabsorbable components of the meshes. The new designs promoted the development of the classification of the meshes as high, medium and low weight, respectively values above $80 \mathrm{~g} / \mathrm{m}^{2}$, between $50-80 \mathrm{~g} / \mathrm{m}^{2}$ or below $50 \mathrm{~g} / \mathrm{m}^{2}$. Some authors define as ultra light material with a density below $35 \mathrm{~g} /$ $\mathrm{m}^{2}$. The pore size represents an important factor for new designs, as well as the filaments themselves and their spatial distribution ${ }^{6}$.

The most important concept in the development of hernia surgery in recent years is the use of low weight meshes with large pores. The new generation has shown advantages in improving postoperative comfort and in chronic postoperative pain. The Ultrapro ${ }^{\circledR}$ represents a new member in the group of low weight with large pores. 
It consists of a monofilament with low weight and large pores, more than $3 \mathrm{~mm}$ in polypropylene, with the addition of a Monocryl ${ }^{\circledR}$ (polyglecrapone 25) absorbable component that optimizes the implant, increasing the resistance of the corrected wall in the first weeks after the repair. Monocryl ${ }^{\oplus}$ is fully absorbed without increased cellularity, inflammatory process and intense fibrotic reaction between 84-140 days. The mesh being partially absorbable and absorbing part of its components, reduces the amount of foreign matter without compromising its biomechanical resistance ${ }^{10}$.

It is known that polypropylene meshes cause early and persistent fibrosis. The reduction is directly proportional to the reduction of its weight and the formation of the fibrosis bridges, inversely proportional to the size of the pores ${ }^{11}$

The present experiment aimed to study the effect of the application of absorbable and non-absorbable meshes as reinforcement in the closure of preperitoneal abdominal wall lesions in rats.

\section{METHOD}

The project was submitted and approved by the Animal Use Ethics Committee (CEUA) of the State University of Ponta Grossa, Process n 037/2014.

A total of 90 Wistar rats (Rattus norvergicus albinus), males, young adults, with three months weighing 280-300 g from the Central Bioterio of the State University of Ponta Grossa were used. The animals were divided into three groups of 30 (Prolene ${ }^{\circledast}$, Ultrapro ${ }^{\circledR}$ and Bard Soft ${ }^{\circledR}$. All groups underwent similar surgical procedures. In the Prolene ${ }^{\circledast}$ group, the nonabsorbable, high-density monofilament mesh with micropores measuring approximately $0.9 \mathrm{~mm}^{2}$, composed of polypropylene with an estimated weight of $100 \mathrm{~g} / \mathrm{m}^{2}$ (Figures $1 \mathrm{~A}$ and 1B) was used. In the Ultrapro ${ }^{\circledast}$ group was used the partially absorbable, low density monofilament with an estimated weight of $28 \mathrm{~g} / \mathrm{m}^{2}$ with macropores of 3-4 mm in size composed of a combination of equal parts of polypropylene and polyglecaprone (Figures $1 C$ and 1D). In the Bard Soft ${ }^{\circledR}$ group, the non-absorbable, low density monofilament mesh with an estimated weight of 44 $\mathrm{g} / \mathrm{m}^{2}$ with macropores of approximately $6.29 \mathrm{~mm}^{2}$, composed of polypropylene (Figures 1E and 1F), was used

Each group was divided into three subgroups of 10, with G1, G3 and G7 with Prolene ${ }^{\circledR}$ implant being evaluated respectively at 30,60 and 120 postoperative days; group Ultrapro ${ }^{\circledR} \mathrm{G} 2, \mathrm{G} 4$ and G8, evaluated on the same days; group Bard Soft ${ }^{\oplus}, \mathrm{G} 5, \mathrm{G} 6$ and $\mathrm{G} 9$ in an identical manner (Table 1).

TABLE 1 - Distribution of groups and subgroups

\begin{tabular}{|c|c|c|c|}
\hline Groups & Mesh & Period of time & Subgroups \\
\hline \multirow{3}{*}{ Prolene } & \multirow{3}{*}{ Prolene ${ }^{\circledR}$} & 30 days & G1 \\
\hline & & 60 days & G3 \\
\hline & & 120 days & G7 \\
\hline \multirow{3}{*}{ Ultrapro } & \multirow{3}{*}{ Ultrapro ${ }^{\circledR}$} & 30 days & G2 \\
\hline & & 60 days & G4 \\
\hline & & 120 days & G8 \\
\hline \multirow{3}{*}{ Bard Soft } & \multirow{3}{*}{ Bard Soft ${ }^{\circledR}$} & 30 days & G5 \\
\hline & & 60 days & G6 \\
\hline & & 120 days & G9 \\
\hline
\end{tabular}

The rats underwent preoperative fasting of $12 \mathrm{~h}$ and anesthetized with atropine sulfate $(0.05 \mathrm{mg} / \mathrm{kg}$ body weight) intraperitoneally, and after $10 \mathrm{~min}$ the mixture of $2 \%$ xylazine hydrochloride $(10 \mathrm{mg} / \mathrm{kg})$ and hydrochloride of ketamine $10 \%$ $(25 \mathrm{mg} / \mathrm{kg})$. When necessary, half the dose was repeated after 20-30 min. They were submitted to postoperative analgesia with oral acetaminophen in the dose of 40 drops for each 500 $\mathrm{ml}$ of water offered in the first two days.

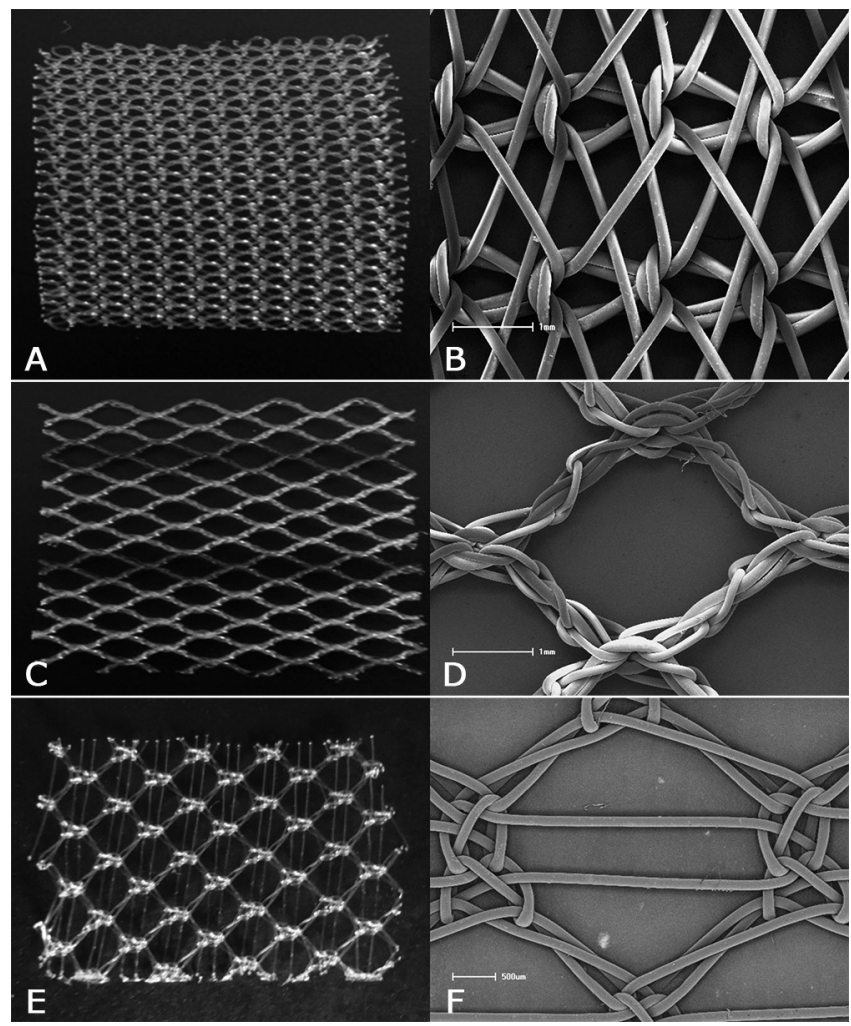

FIGURE 1 - Meshes used in the experiment and, next to it, their scanning electron microscopy visualization: $A$ and $B$ ) Prolene ${ }^{\circledR} ; C$ and D) Ultrapro ${ }^{\circledR} ; E$ and F) Bard Soft ${ }^{\circledR}$

A defect of $1 \times 2 \mathrm{~cm}$ was produced in the abdominal wall, preserving the integrity of the parietal peritoneum. Correction was performed using each of the $1.5 \times 2.5 \mathrm{~cm}$ area meshes fixed in the extraperitoneal position through four separate stitches of Prolene ${ }^{\circledR}$ 5- 0 wire securing the mesh angles to the aponeurosis of the abdominal wall, $0.5 \mathrm{~cm}$ from the edge of the lesion, and four separate stitches interspersed with the first ones, securing the lesion at the edges of the lesion (Figure $2-A, B$ and C). The skin was sutured with intradermal 5-0 mononylon intradermal.

Euthanasia was performed at the defined dates (Table 1). At that time, macroscopic evaluation of the operative wound and the peritoneal cavity was made, and a fragment of the wall was removed, which, divided into a median section, gave rise to a cranial and a caudal fragment. The segment containing the mesh and musculature (cranial), without the skin, was submitted to tensiometric tests. The caudal fragments were maintained in $10 \%$ formalin solution. The cranial segments were placed in vials with isotonic saline solution and kept in vials with ice.

For tensiometry, the Shimadzu (Japan) model AG-I tensiometer was used with Trapezium 2 software, where the data provided for the test (area and thickness of the tissue) and the results obtained were recorded. The tests were performed at a temperature of $24^{\circ} \mathrm{C}$. The apparatus was calibrated for a speed of $50 \mathrm{~mm} / \mathrm{min}$. The results were expressed as $\mathrm{N} / \mathrm{cm}$. The cranial fragment was attached to the tensiometer by the muscular tissues next to the suture site.

\section{Statistical analysis}

The means between the results of the tensiometry were submitted and approved in the normality test of KS (Kolmogorov and Smirnov), suggesting parametric inference tests. From unpaired ANOVA, evidence of significant differences, at the $5 \%$ level, was found between treatments in relation to tensiometry in the replicates, thus rejecting the null hypothesis at these points of observation. 


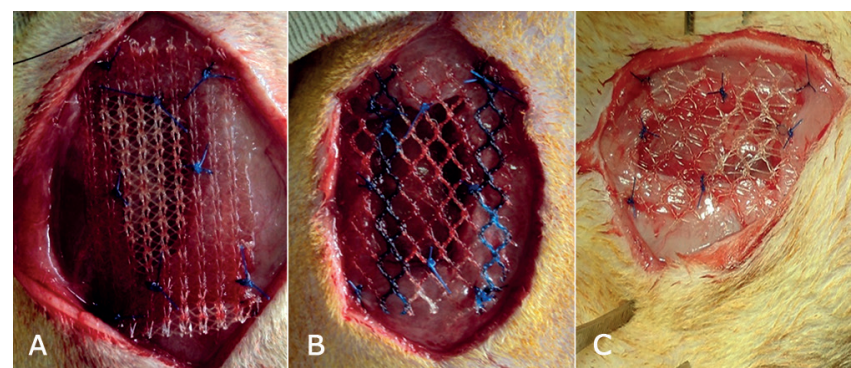

FIGURE 2 - Meshes applied to the abdominal wall defect: A) Prolene $^{\circledast}$; B) Ultrapro ${ }^{\oplus}$; C) Bard Soft ${ }^{\circledast}$

\section{RESULTS}

\section{Macroscopic and tensiometric evaluations}

No animal presented any complications, and the edges of the mesh fixation to wounds were fully coapted in all animals.

In tissue tensiometry with implanted tissue, it was found that the rupture always occurred outside the suture line of the mesh in the abdominal wall.

The mean stress at break of subgroup G5 (Bard Soft ${ }^{\circledR}$ ) at 30 days was $32.32 \mathrm{~N} / \mathrm{cm}$, higher than the mean tension at subgroup G1 (Prolene ${ }^{\circledast}$ ) of $21.73 \mathrm{~N} / \mathrm{cm}(\mathrm{p}<0.01)$. The $\mathrm{G} 2$ (Ultrapro $^{\circledast}$ ) subgroup with mean tension of $24.49 \mathrm{~N} / \mathrm{cm}$ at 30 days did not present a statistically significant difference in relation to $\mathrm{G} 5$ (Bard $\mathrm{Soft}^{\circledR}$ ) subgroups with mean rupture stress of $32.32 \mathrm{~N} / \mathrm{cm}$, and G1 (Prolene ${ }^{\circledast}$ ) with mean tension at the same time of $21.73 \mathrm{~N} / \mathrm{cm}(\mathrm{p}>0.05)$.

On the $60^{\text {th }}$ postoperative day, the subgroup $\mathrm{G} 6$ (Bard Soft $^{\circledR}$ ) showed a mean rupture tension of $36.36 \mathrm{~N} / \mathrm{cm}$ statistically superior to the subgroup G3 (Prolene ${ }^{\circledast}$ ), with a mean tension of rupture of $24 \mathrm{~N} / \mathrm{cm}(\mathrm{p}<0.05)$. The comparison between $\mathrm{G} 4$ (Ultrapro ${ }^{\circledR}$ ) subgroup that presented mean tension at 26.12 $\mathrm{N} / \mathrm{cm}$ at 60 postoperative days, G3 (Prolene $^{\circledast}$ ) subgroups with mean tension at $24 \mathrm{~N} / \mathrm{cm}$ and $\mathrm{G} 6$ (Bard Soft ${ }^{\oplus}$ ) with mean rupture stress of $36.26 \mathrm{~N} / \mathrm{cm}$, did not show a statistically significant difference $(p>0.05)$.

TABLE 2 - Mean and standard deviation of burst voltage $(\mathrm{N} / \mathrm{cm})$

\begin{tabular}{ccccc} 
& \multicolumn{4}{c}{ Repetitions } \\
\cline { 2 - 5 } Treatment & \multicolumn{4}{c}{ Time (days) } \\
\cline { 2 - 5 } & 30 & 60 & 120 \\
\multirow{3}{*}{ Materials } & Prolene & $21.73 \pm 4.47$ & $24.00 \pm 11.36$ & $33.40 \pm 9.99$ \\
\cline { 2 - 5 } & Ultrapro & $24.49 \pm 7.78$ & $26.12 \pm 7.75$ & $46.77 \pm 6.54$ \\
\cline { 2 - 5 } & Bard Soft & $32.32 \pm 8.47$ & $36.26 \pm 7.41$ & $37.78 \pm 5.90$
\end{tabular}

TABLE 3 - Comparison of the means of rupture stress $(\mathrm{N} / \mathrm{cm})$

\begin{tabular}{|c|c|c|c|}
\hline $\begin{array}{c}\text { Period of } \\
\text { observation (days) }\end{array}$ & $\begin{array}{l}\text { Mean of } \\
\text { tensiometry }\end{array}$ & & \\
\hline \multirow[t]{3}{*}{ - } & $\mathrm{G} 5>\mathrm{G} 1$ & $p<0.01$ & \multirow{3}{*}{$p=0.0073$} \\
\hline & $\mathrm{G} 2=\mathrm{G} 5$ & $p>0.05$ (ns) & \\
\hline & $\mathrm{G} 2=\mathrm{G} 1$ & $p>0.05$ (ns) & \\
\hline \multirow{3}{*}{60} & $\mathrm{G} 6>\mathrm{G} 3$ & $p<0.05$ & \multirow{3}{*}{$p=0.0117$} \\
\hline & $\mathrm{G} 4=\mathrm{G} 3$ & $p>0.05$ (ns) & \\
\hline & $\mathrm{G} 4=\mathrm{G} 6$ & $p>0.05$ (ns) & \\
\hline \multirow{3}{*}{120} & $\mathrm{G} 7=\mathrm{G} 9$ & $\mathrm{p}>0.05$ (ns) & \multirow{3}{*}{$p=0.0020$} \\
\hline & $\mathrm{G} 8>\mathrm{G} 7$ & $p<0.01$ & \\
\hline & $\mathrm{G} 8>\mathrm{G} 9$ & $p<0.05$ & \\
\hline
\end{tabular}

On the $120^{\text {th }}$ postoperative day, the tensiometric analysis showed a statistically significant difference between the subgroup G8 $\left(\right.$ Ultrapro ${ }^{\circledR}$ ), which presented a mean tension at $46.77 \mathrm{~N} / \mathrm{cm}$, higher than the tension of the subgroups G7 (Prolene ${ }^{\circledR}$ ) with mean tension of rupture of $33.4 \mathrm{~N} / \mathrm{cm}(p<0.01)$ and subgroup G9 (Bard Soft ${ }^{\circledR}$ ) with mean rupture stress of $37.78 \mathrm{~N} / \mathrm{cm}$. Among the G7 and G9 subgroups there was no statistically significant difference $(p>0.05)$ (Tables 2 and 3, Figure 3).

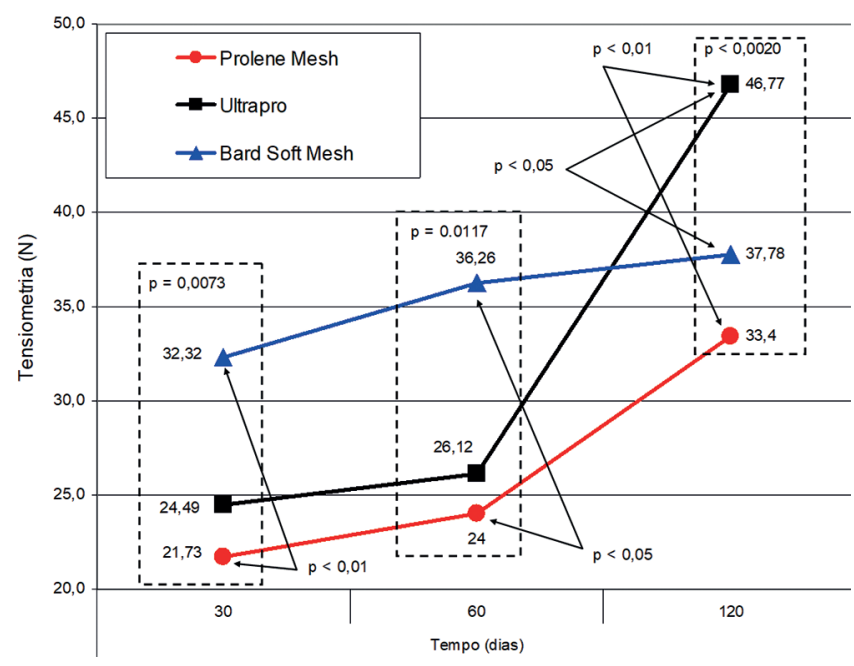

FIGURE 3 - Comparison of the mean tensile stress

\section{DISCUSSION}

\section{Surgical meshes}

The evolution of polypropylene prostheses has revolutionized surgery to correct abdominal wall defects. The creation of the low-weight prosthesis theoretically induced a smaller foreign body reaction, resulting in an improvement of the abdominal wall, causing less contraction of the mesh and providing better incorporation of the abdominal wall ${ }^{5,9,4}$.

Numerous modifications in the designs of the prostheses have been investigated for the reduction of the complications related to the healing process. Alteration of the architecture, increase of the pore area and low weight mesh, are the most important predictors of the biocompatibility performance of synthetic meshes. Those with broad pores show less inflammatory infiltrate, connective tissue and fibrosis bridges ${ }^{18}$.

The prostheses for this study were chosen based on the wide use of polypropylene today, and considering that there are few studies comparing the low and high density meshes used in the extraperitoneal space in the period over 100 days.

Greca et al. ${ }^{5}$ in studies with dogs comparing low and high-weight polypropylene meshes on the abdominal wall including the peritoneum had incidence of $20 \%$ of seroma in both, $5 \%$ of infection in high-weight Prolene ${ }^{\circledast}$, dehiscence in $9.1 \%$ in the low-weight group and $4.6 \%$ in the high-weight group, and there was no incorporation of the mesh in $5 \%$ of the high-weight group. In this study, there was no complication in the group as a whole.

In tissue tensiometry rupture was observed always outside the suture line, a result also obtained by Aydos et al. ${ }^{1}$ and Pundek et al. ${ }^{15}$

Cobb et al. ${ }^{4}$ showed that after the implant of highweight and low-weight mesh showed a significant increase of deposition of collagen type I on the one with larger pores of low-weight. The rupture tension increased after 30 days of implantation in dogs, although the same occurred in the high-weight mesh with smaller pores. A similar study evaluated the high-weight polypropylene mesh with pores smaller than $1 \mathrm{~mm}$ with a low-weight and pores larger than $3 \mathrm{~mm}\left(\right.$ Vypro $\left.^{\circledR}\right)$, but with an absorbable component. The wide pore mesh was integrated with loose deposition of fibrosis interspersed with fatty tissue. In contrast, that of pores smaller than $1 \mathrm{~mm}$, was incorporated entirely with peri filamentary granulomas and scar tissue, forming bridges between the pores. It has been proven that the great distance between filaments avoids the formation of these bridges. 
The results of this study, in the comparison of the mean of rupture tension between the G1 (Prolene ${ }^{\circledR}$ ) and G5 (Bard Soft ${ }^{\oplus}$ ) subgroups on the $30^{\text {th }}$ day and between the $\mathrm{G} 3$ (Prolene ${ }^{\circledast}$ ) and G6 (Bard Soft ${ }^{\circledR}$ ) subgroups on day 60 showed greater resistance of the subgroups G5 and G6 (Bard Soft ${ }^{\oplus}$ ), and on the $120^{\text {th }}$ day a significant increase of resistance in subgroup G8 (Ultrapro ${ }^{\circledR}$ ) in relation to subgroups G7 (Prolene ${ }^{\circledR}$ ) and G9 $\left(\right.$ Bard Soft $\left.{ }^{\circledast}\right)$. The pore size of the mesh has important influence on the biocompatibility of the foreign body after the implant.

The results of this study show that despite fixation of the prosthesis with only four separated stitches in the aponeurosis and four intercalated fixation of the prosthesis in the border of the lesion, the incorporation was sufficient to avoid the suture dehiscence and the rupture of the suture line during the tensiometry in all the prostheses used ${ }^{16}$.

The results of this study also showed that at 120 days there is greater resistance of the corrected wall with the Ultrapro ${ }^{\circledast}$ prosthesis, which has pores with a diameter greater than $3 \mathrm{~mm}^{2}$ and a weight of approximately $28 \mathrm{~g} / \mathrm{m}^{2}$, compared to Prolene ${ }^{\circledR}$ prostheses - whose pores have a diameter of less than $1 \mathrm{~mm}^{2}$ and approximate weight of $100 \mathrm{~g} / \mathrm{m}^{2}$ - and Bard Soft ${ }^{\oplus}$ - with a pore size of approximately $6.29 \mathrm{~mm}^{2}$, but weighing approximately $44 \mathrm{~g} / \mathrm{m}^{2}$. This increase in resistance is shown to be even higher when tissue resistance is compared with the implantation of the Bard Soft ${ }^{\circledR}$ prosthesis in 30 and 60 days, which has a larger pore diameter ${ }^{5,1,13}$. It is observed that the Bard Soft ${ }^{\circledast}$ mesh despite having a pore with a larger diameter than the Ultrapro ${ }^{\circledR}$, has a higher density depending on the mesh design ${ }^{2}$.

White et al. ${ }^{17}$ reported that complete tissue incorporation into the recipient tissue is an important requirement for obtaining solid repair. The degree of infiltration of the receptor tissue with the biomaterial depends on the pore size. The incorporation of the prosthesis into the recipient tissue is proportional to the degree of its porosity. The infiltration of fibrocytes and collagen from the recipient tissue into the prosthesis with adequate porosity occurs in approximately one month. Adequate incorporation requires pores between 75 and $100 \mu \mathrm{m}$ in size. The mesh with polypropylene monofilament, with pore greater than $100 \mu \mathrm{m}$, produces complete infiltration of the receptor tissue incorporating the entire prosthesis.

Studies ${ }^{4,13,8}$ confirm good integration of high- and lowweight prostheses in the repaired tissues. There is greater encapsulation in the high-weight meshes and consequent hardening of the corrected wall and better distribution of the of fibrosis between the filaments of the low-weight, providing better elasticity and malleability of the corrected wall.

\section{CONCLUSIONS}

The tissues repaired with macroporous meshes showed greater resistance than the microporous ones in all the phases, being that at 120 days of postoperative the Ultrapro ${ }^{\circledR}$ had better performance than the others.

\section{REFERENCES}

1. Aydos RD, Silva IS, Goldenberg S, Goldenberg A, Simões M J, Takita LC, NigroAJT.Estudo comparativo do efeito das telas de politetrafluoetileno expandido e de polipropileno, colocadas por laparoscopia, em hérnias ventrais produzidas em coelhos. Acta Cir. Bras. 1999; 14(2): 59-64.

2. Bellón J M. Implicaciones de los nuevos diseños protésicos de baja densidade em la mejora de la reparación de defectos herniarios. Cirugía Española. 2009;85(5): 268-273.

3. Bosi HR, Guimarães JR and Cavazzola LT.Robotic assisted single site for bilateral inguinal hernia repair.ABCD, arq. bras. cir. dig., June 2016, vol.29, no.2, p.109-111. ISSN 0102-6720.

4. Cobb WS, Kercher WK, Heniford TB. The Argument for Lightweight Polypropylene Mesh in Hernia Repair. Surgical Innovation. March 2005; 12: T1-T7.

5. Greca FH, de Paula JB, Biondo-Simões MLP, da Costa FD, da Silva APG, Time $S$, Mansur A. The influence of differing pore sizes on the biocompatibily of two polypropylene meshes in the repair of abdominal defects. Hernia. June, 2001; 5: 59-64.

6. Hernández-Gascón B, Peña E, Melero H, Pascual G, Doblaré M, Ginebra M P, Bellón J M, Calvo B. Mechanical behavior of syntethic surgical meshes: finite element simulation of the herniated abdominal wall. Acta Biomaterialia. 2011; 7: 3905-3913.

7. luamotoLR, KatoJM,MeyerA, BlancP.Laparoscopictotallyextraperitoneal (TEP) hernioplasty using two trocars: anatomical landmarks and surgical technique.ABCD, arq. bras. cir. dig., June 2015, vol.28, no.2, p.121-123. ISSN 0102-6720.

8. KlingeU, Klosterhalfen B, BirkenhauerV, Junge K, Conze J, SchumpelickV. Impact of Polymer Size on the Interface Scar Formation in a Rat Model. Journal of Surgical Research. March, 2002; 103: 208-214.

9. Klinge U, Klosterhalfen B, Conze J, Limberg W, Obolenski B, Ottinger $A P$, Schumpelick V. Modified mesh for hernia repair that is adapted to the physiology of the abdominal wall. European Journal Surgery. 1998; 164: 951-960.

10. Klosterhalfen $B$, Junge $K$, Klinge $U$. The lightweight and large porous mesh conceptforhernia repair. Expert Rev Med Devices. 2005;2:103-117.

11. Orestein B S M.D, Saberski R E, Bs., Kreutzer L D, Ph.D., Novitski W Y M.D.ComparativeAnalysis ofHistopahologicEffects ofSynthetic Meshes Based omn Material, Weight, and Pore Size in Mice. Journal of Surgical Research. 2012; 176: 423-429.

12. Palermo M, Acquafresca Pablo A; Bruno M, Tarsitano F. Without mesh: Analysis of the immediate complications in a randomized controlled clinical trial.ABCD, arq. bras. cir. dig., Sept 2015, vol.28, no.3, p.157-160. ISSN 0102-6720.

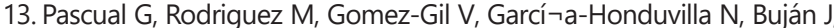
BellónJM.Earlytissueincorporationand collagendepositioninlightweight polypropylene meshes: bioassay in an experimental model of ventral hernia. Surgery. Sep 2008; 144(3): 427-35.

14. Pascual G, Rodriguez M, Sotomayor S, Perez-Köhler B, Bellón J M. Inflammatory reaction and neotissue maturation in the early host tissue incorporation of polypropylene prostheses. Hernia 2012; 16:697-707.

15. Pundek MRZ, Czeczko NG, Yamamoto CT, Pizzato RF, Czeczko LEA, Dietz UA Malafaia O. Estudo das telas cirúrgicas de polipropileno/ poliglecaprone e de polipropileno/polidiaxona/cellulose oxidada regenerada na cicatrização de defeitos produzidos na parede abdominal de ratos. Arquivos Brasileiros de Cirurgia Digestiva. 2010; 23(2): 94-99.

16. Utrabo CAL, Czeczko NG, Busato CR, Montemor-Netto MR, Malafaia O, DietzAU.Comparativestudybetween polypropyleneand polypropylene/ poliglecaprone meshes used in correction of abdominal wall defects in rats. 2012; 27(4): 300-305.

17. WhiteRA, HiroseFM,SproatRW, Lawrence R.S, NelsonRG. Histophatologic observations after short-term implantation of two porous elastomers in dogs. Biomaterials. 1981; 2: 171-176.

18. Z Lei-Ming, Schuster P, Klinge U. Mesh implantes: An overview of crucia mesh parameters. Word Journal of Gastrointestinal Surgery.2015October 27; 7(10): 226-236. 